\title{
Assessment of community knowledge, attitude and practice on common zoonotic diseases in Jinka town, Southern Ethiopia
}

\author{
Haben Fesseha ${ }^{1 *}$, Fasil Abebe ${ }^{2}$ \\ ${ }^{1}$ School of Veterinary Medicine, Wolaita Sodo University, P.O. Box 138, Wolaita Sodo, Ethiopia. \\ ${ }^{2}$ College of Veterinary Science, Mekelle University, P. O. Box 2084, Mekelle, Ethiopia \\ Address for correspondence: \\ Haben Fesseha, School of Veterinary Medicine, Wolaita Sodo University, P.O. Box 138, Wolaita Sodo, Ethiopia. E-mail: tseyon.h@gmail.com \\ Submitted: 22 July 2020 \\ Approved: 29 July 2020 \\ Published: 30 July 2020 \\ How to cite this article: Fesseha H, Abebe F. Assessment of community knowledge, attitude and practice on common zoonotic diseases in \\ Jinka town, Southern Ethiopia. G Med Sci. 2020; 1(3): 018-029. https://www.doi.org/10.46766/thegms.virology.20072206 \\ Copyright: $\odot 2020$ Haben Fesseha, Fasil Abebe. This is an open access article distributed under the Creative Commons Attribution License, which per- \\ mits unrestricted use, distribution, and reproduction in any medium, provided the original work is properly cited.
}

\section{ABSTRACT}

\begin{abstract}
A cross-sectional study was conducted from November 2018 to May 2019 in and around Jinka town, to assess the community's knowledge, attitude, and practice on common zoonotic disease. A total of 330 randomly selected participants had voluntarily filled the semi-structured questionnaire. Accordingly, age, religion, education, occupation and marital status of the respondents were significantly associated with their knowledge on the zoonotic disease in which respondents with the age group greater than 15 years, orthodox and catholic religious affiliations, health professionals and married ones had greater knowledge towards zoonotic disease $(\mathrm{P}<0.05)$. The effect of educational background of the respondents on their attitude towards zoonotic disease treatment, prevention, control, and advantages of vaccine provision was found to be statistically significant. Among those who have a positive perception of zoonotic treatment, about $35.8 \%$ of respondents were having college and university education while $49.2 \%$ of those who didn't have a positive perception of the zoonotic disease treatment were illiterate. The educational level of the respondents was significantly associated with their practices towards zoonotic diseases $(\mathrm{P}<0.05)$. Respondents with lower educational levels had higher contact with animals, consume more raw meat, didn't take pre-exposure vaccination, and didn't take immediate action for infected animals by zoonotic diseases. In conclusion, community education and awareness programs are required for further improvement of the knowledge, attitude, and practice of the community on zoonotic diseases. Besides, the integration of one health approach towards the control of zoonotic diseases is important.
\end{abstract}

Keywords: Attitude, Education, Knowledge, Jinka, Practices, Zoonosis

\section{Introduction}

Generally, zoonotic diseases had a tremendous impact on the evolution of man, especially those cultures and societies that domesticated and bred animals for food and clothing [1]. Zoonotic diseases can be acquired or spread in a variety of ways: through the air (aerosol), by direct contact, by contact with an inanimate object that harbors the disease (fomite transmission), by oral ingestion, and by insect transmission [2]. Zoonotic diseases cause mortality and morbidity in people, while also imposing significant economic losses in the livestock sector [3]. 
Zoonotic infections originate and spread at the interface between humans, animals, and their environments, making them candidates for the One Health approach to disease control [4]. Although international organizations, government authorities, and academic institutions, believe the One Health concept should be a part of a local community's response to zoonotic infection, the One Health concept is rarely implemented at the community level. It is undeniable that community involvement is crucial in reducing the risk of zoonotic diseases at the interface between animal-human and their ecosystem [5][6].

Most known human infectious diseases and approximately three-quarters of newly emerging infections come from animals [7][8]. Zoonotic diseases have the potential to impact society in three main ways: (1) They threaten the health of animals resulting in illness, loss of productivity, and death; (2) They threaten the livelihood of people dependent on livestock as a major source of income; and (3) They cause illness and death in people, which in turn causes additional economic and societal loss. Ethiopia also ranks very high in the health burden of zoonotic diseases and in having a large population of poor livestock keepers [9][10].

The organisms causing zoonosis include viruses, bacteria, fungi, protozoa, and other parasites, with both domestic and wild animals acting as reservoirs for the pathogens. The diseases cause in humans ranges from mild and self-limiting (such as most cases of toxoplasmosis) to fatal (like Ebola hemorrhagic fever) with a variety of animal reservoirs, including wildlife, livestock, pet animals, and birds [11].

The link among humans, animal populations, and the surrounding environment is very close in many developing countries, where animals provide transportation, draught power, fuel, clothing, and sources of protein (that is, meat, eggs, and milk) [3][12]. In rural parts of Ethiopia, people are mainly dependent on animals and their relationship with them is very close. People often consume raw animal products that may predispose them to zoonotic disease as Mycobacterium bovis and Brucellosis infection [13]. Many parasitic zoonoses are widely present in Ethiopia [12].

Lack of awareness about zoonotic diseases is one of the most important reasons for the outbreak of zoonotic diseases in people. Occupational risks for exposure to zoonotic diseases are a concern for persons such as farmers, meatpackers and pet shop employees who work with animals. Even though the government is practicing most disease control schemes including vaccination, organization of animal health camps, compensation to livestock owners for the infected animal that are culled are not very feasible in most developing countries, mainly because of limited resources [6][14].

Improving awareness among the livestock owners and proper disease diagnostic techniques could be helpful in the prevention and control of zoonotic diseases. Hence, understanding public awareness and practice of farmers have received much attention nowadays and it could be a useful tool in developing and improving existing control measures. Both veterinarians and physicians must be involved in the control of zoonotic disease because the latter do not usually consider the role of animals in the transmission of disease and the former do not receive extensive training on clinical aspects of human disease [15][16].

The global public health burdens generated by HIV/AIDS, SARS, avian influenza (H5N1), and some other zoonotic diseases, brought about countries' mutual dependency. The mutual dependency was an incentive because no single country or few countries could have overcome the burdens alone. And also it brought a reminder that global effective disease response cannot be mobilized by a single segment or group of professionals. The experience made the international community came across the forgotten "concept of One Health" [17].

"One Health Initiative" approach introduction takes a general strategy to combine human, animal, and ecosystem health, which means, it connects human medical and veterinary science. The major steps of "One Health" in the prevention and control of zoonosis emergence are surveillance, identification, Investigation, and also collaboration [18][19]. The international and interdisciplinary interventions involve advance structures development for surveillance and diagnosis, ecological and applied epidemiological research, education/training, and information/communication [20].

Among the most important targets to meet is building robust and well-governed public health and animal health system compliant with the WHO and OIE international standards. Additional targets consist of emphasizing the importance of cross-sectoral collaboration and coordination, together with motivating trainees to abandon traditional behaviors and better inform decision-makers to obtain the necessary political, legal, and financial support. Hence an understanding of public awareness and practices of farmers has received much attention nowadays could be a useful tool in developing and improving existing control measures [21][22]. Therefore, the research was conducted with the objectives to assess community knowledge and attitude on zoonotic disease and to assess the practice of the society on integrated 'One Health' approach in controlling zoonotic disease in Jinka town, South Omo, Ethiopia. 


\section{MATERIALS AND METHODS}

\subsection{Study Area}

The study was conducted from November 2018 to May 2019 in Jinka town which is the administrative center of South Omo zone and located $733 \mathrm{Km}$ south of Addis Ababa, in Southern nations and nationalities and people regional state, Ethiopia. South Omo is a zone in the Ethiopian Southern nations, nationalities and peoples region, which is bordered on the south by Kenya, on the southwest by the Ilemi Triangle, on the west by Bench Maji, on the northwest by Keffa, on the north by Konta, Gamo Gofa and Basketo, on the northeast by Dirashe and Konso, and the east by the Oromia Region. The majority of the zone is occupied by pastoralists living in the lowlands and semi pastoralists and farmers in the highlands. Altogether 16 tribes are living in South Omo Zone divided into 8 woredas [23].

\subsection{Study Population}

The study population included individuals who were resident in Jinka town with different Socio-demographic characteristics. This study includes individuals of both sex, different age categories, different religions and occupation, different marital statuses, and those which were found on different educational levels. Besides, the target populations were interviewed with specific questions related to knowledge, attitude, and practice of the community regarding one health approach to the control of the zoonotic disease.

\subsection{Study Design}

A cross-sectional study was carried out from November 2018 to May 2019 to assess the awareness of the community's knowledge, attitude, and practice of integrated one health approach to controlling zoonosis disease. The study was conducted in selected sites of Jinka town that were considered during the study. Accordingly, all individuals who live within the selected sites were randomly selected.

\subsection{Sample Size Determination}

The study population of the current study comprised of randomly selected students of different educational levels (elementary, high schools, colleges), farmers, and governmental and self-employees that are found in Jinka town and its surroundings. Thus, the required sample size for this study was estimated by considering the formula given by Yemane [24] for the questionnaire survey. A 95\% confidence interval was considered to calculate the sample size. A total of 330 study participants were selected to increase precision.

$\mathrm{n}=\mathrm{N} /\left(1+\mathrm{N}^{*}(\mathrm{e})^{2}\right)$

Where $\mathrm{n}$-sample size,

$\mathrm{N}$-population size $=31,000$ Jinka Population (South Omo Zone Statistical Bureau)

e-acceptable sampling error

*95\% confidence level and $\mathrm{p}=0.05$ are assumed. Hence, the total sample size was calculated to be 400 .

\subsection{Method of Data Collection}

A questionnaire was presented to each randomly selected individuals. The questionnaire survey was carried out by interviewing individuals about their Socio-demographic characteristics followed by specific questions related to knowledge, attitude, and practice of the community regarding one health approach to the control of zoonosis disease.

\subsection{Study Methodology}

A structured questionnaire was prepared to assess the knowledge, attitude, and practice (KAP) of the community settled on urban and peri-urban areas of the study areas. The questionnaire was administered to the population who live within Jinka town and properly translated to the local language "Amharic" during the interview. Besides, they were briefed about the objective of the survey and asked for their consent before the interview was commenced.

The KAP tool focused on the knowledge and attitude of the community on causes, symptoms, transmission methods, negative impact, and treatment, control, and prevention as well as mechanisms of zoonosis. Besides, it focuses on animal products and consumption behavior, vaccination of pets, contact with soil, source of drinking water, etc. 


\subsection{Data Analysis}

The questionnaire data were entered into the Microsoft Excel 13 spreadsheet application program and imported to STATA version-13 statistical software for descriptive statistical analysis, hypothesis testing, and test of association between different risk factors and outcome variables. Pearson's Chi-square test was used to detect the existence of an association between variables. In order to consider a result to be statistically significant $95 \% \mathrm{CI}$ and p-value, less than 0.05 were considered.

\section{RESULTS}

\subsection{Socio-Demographic Status of Respondents}

A total of 330 respondents were included in this survey study with $18 \%$ of the non-response rate. The study included slightly more women $(57.3 \%)$ than men $(42.7 \%)$, and about $36.4 \%$ were Illiterate. About $35.2 \%$ were between $31-50$ years of age which is the most productive age. The majority of the respondents were reported to be Orthodox (39.1\%) rather than other religions. Besides, the majority (40.3\%) of the heads of households were married (Table1). Jobless and peoples who work on other sectors $(28.5 \%)$ were the most respondents followed by farmers and students.

Table 1. Socio-demographic characteristics of respondents in the Jinka town

\begin{tabular}{|c|c|c|c|}
\hline \multicolumn{2}{|l|}{ Variables } & Frequency & Percentage (\%) \\
\hline \multirow[t]{2}{*}{ Sex } & Male & 141 & 42.7 \\
\hline & Female & 189 & 57.3 \\
\hline \multirow[t]{4}{*}{ Age } & Less than 15 & 37 & 11.2 \\
\hline & Between 15-30 & 90 & 27.3 \\
\hline & Between 31-50 & 116 & 35.1 \\
\hline & Greater than 50 & 87 & 26.4 \\
\hline \multirow[t]{5}{*}{ Religion } & Orthodox & 129 & 39.1 \\
\hline & Catholic & 65 & 19.7 \\
\hline & Protestant & 46 & 13.9 \\
\hline & Muslim & 69 & 20.9 \\
\hline & Others & 21 & 6.4 \\
\hline \multirow[t]{4}{*}{ Education } & Illiterate & 120 & 36.4 \\
\hline & Elementary & 65 & 19.7 \\
\hline & High school & 54 & 16.4 \\
\hline & Colleges and university & 91 & 27.6 \\
\hline \multirow[t]{7}{*}{ Occupation } & Farmers & 78 & 23.6 \\
\hline & Merchant & 37 & 11.2 \\
\hline & Student & 62 & 18.8 \\
\hline & Health professionals & 35 & 10.6 \\
\hline & Administrative & 13 & 3.9 \\
\hline & Teachers & 11 & 71.5 \\
\hline & Other & 94 & 28.5 \\
\hline \multirow[t]{4}{*}{ Marital status } & Single & 79 & 23.9 \\
\hline & Married & 133 & 40.3 \\
\hline & Widow & 87 & 26.4 \\
\hline & Divorced & 31 & 9.4 \\
\hline
\end{tabular}




\subsection{Knowledge of the Respondents on Zoonotic Disease}

The association of sex, age, religion, education level, occupation, and marital status of the respondent with knowledge related to zoonotic disease was analyzed using chi-square. The result showed that females had higher knowledge of the zoonotic disease $(17.5 \%)$ than males and there was no statistically significant difference $(P>0.05)$ between sex of respondent and knowledge about zoonosis. However, the age of respondents were significantly associated with knowledge of respondent $(\mathrm{P}<0.05)$ and respondents between the age of $31-50$ had higher knowledge $(89.6 \%)$.

Similarly, orthodox followers had significantly higher knowledge (90.7\%) than catholic followers and others, besides the result shows a significant association $(\mathrm{P}<0.05)$ of religion with respondent knowledge. Likewise, the educational status of the respondents found to be statistically significantly associated $(\mathrm{P}<0.05)$ with knowledge status with college and university level had higher knowledge (100.0\%) towards zoonotic disease followed by respondents with high school and elementary level (Table 2). Moreover, the occupation had a statistically significant association $(\mathrm{P}<0.05)$ like that of the marital status of the respondents $(\mathrm{P}<0.05)$. The finding shows that health professionals, administrative workers, and teachers had better knowledge of zoonotic disease (100.0\%).

Table 2. Knowledge of respondents regarding zoonotic disease in Jinka town.

\begin{tabular}{|c|c|c|c|c|c|}
\hline \multicolumn{2}{|c|}{ Variables } & \multicolumn{2}{|c|}{$\begin{array}{c}\text { Knowledge related to } \\
\text { Zoonotic Disease } \\
\end{array}$} & \multirow[b]{2}{*}{$\begin{array}{c}\text { Chi-square } \\
\left(\mathrm{X}^{2}\right) \\
\end{array}$} & \multirow[b]{2}{*}{ P-value } \\
\hline & & $\begin{array}{c}\text { Yes } \\
N(\%)\end{array}$ & $\begin{array}{c}\text { No } \\
\text { N (\%) }\end{array}$ & & \\
\hline \multirow[t]{2}{*}{ Sex } & Male & $126(89.4)$ & $15(10.6)$ & 3.02 & 0.08 \\
\hline & Female & $156(17.5)$ & $33(82.5)$ & & \\
\hline \multirow[t]{4}{*}{ Age } & Less than 15 & $23(62.2)$ & $14(37.8)$ & 27.83 & 0.00 \\
\hline & Between 15-30 & $86(95.6)$ & $4(4.4)$ & & \\
\hline & Between 31-50 & $104(89.6)$ & $12(10.4)$ & & \\
\hline & Greater than 50 & $69(79.3)$ & $18(20.7)$ & & \\
\hline \multirow[t]{5}{*}{ Religion } & Orthodox & $117(90.7)$ & $12(9.3)$ & 13.19 & 0.01 \\
\hline & Catholic & $59(90.7)$ & $6(9.3)$ & & \\
\hline & Protestant & $33(71.7)$ & $13(28.3)$ & & \\
\hline & Muslim & $57(82.6)$ & $12(17.4)$ & & \\
\hline & Others & $16(76.2)$ & $5(23.8)$ & & \\
\hline \multirow{4}{*}{$\begin{array}{l}\text { Educational } \\
\text { level }\end{array}$} & Illiterate & $93(77.5)$ & $27(22.5)$ & 28.11 & 0.00 \\
\hline & Elementary & $49(75.4)$ & $16(24.6)$ & & \\
\hline & High school & $49(90.7)$ & $5(9.3)$ & & \\
\hline & $\begin{array}{c}\text { Colleges and } \\
\text { university }\end{array}$ & $91(100.00)$ & $0(0.00)$ & & \\
\hline \multirow[t]{7}{*}{ Occupation } & Farmers & $73(93.6)$ & $5(6.4)$ & 29.94 & 0.00 \\
\hline & Merchant & $27(72.9)$ & $10(27.1)$ & & \\
\hline & Student & $54(87.1)$ & $8(12.9)$ & & \\
\hline & Health professionals & $35(100.00)$ & $0(0.00)$ & & \\
\hline & Administrative & $13(100.00)$ & $0(0.00)$ & & \\
\hline & Teachers & $11(100.00)$ & $0(0.00)$ & & \\
\hline & Other & $69(73.4)$ & $25(26.6)$ & & \\
\hline \multirow[t]{4}{*}{ Marital status } & Single & $60(75.9)$ & $19(24.1)$ & 7.60 & 0.05 \\
\hline & Married & $118(88.7)$ & $15(11.3)$ & & \\
\hline & Widow & $77(88.5)$ & $10(11.5)$ & & \\
\hline & Divorced & $27(87.1)$ & $4(12.9)$ & & \\
\hline
\end{tabular}


As indicated in figure 1, there was a knowledge gap between respondents based on the status of training on the zoonotic disease in which those who took training to have better awareness than those who don't take training on zoonotic disease. This association was statistically significant $(\mathrm{P}<0.05)$.

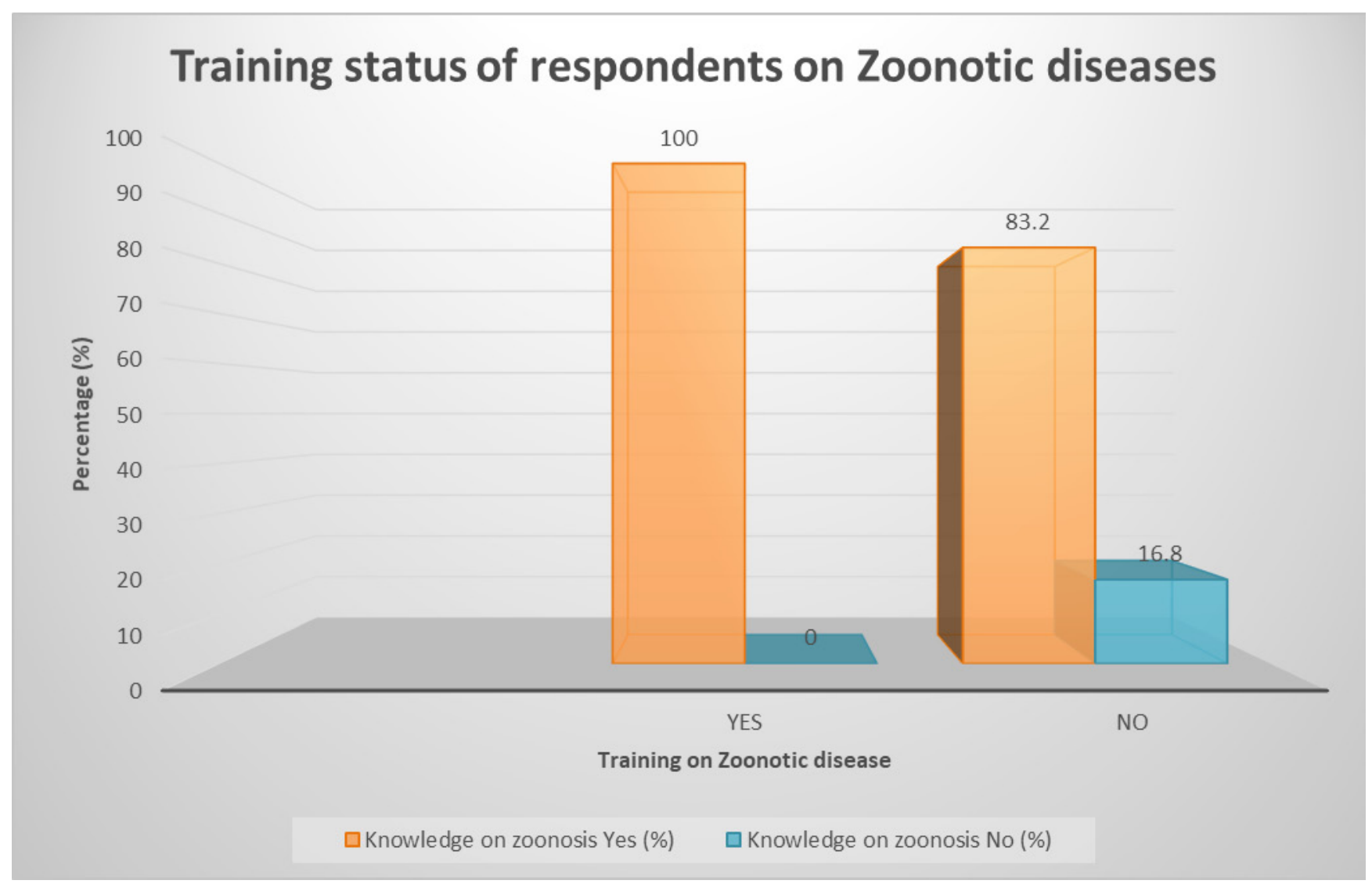

Figure 1: Training status of respondents on knowledge of zoonotic diseases

\subsection{Attitude of the Respondents on Zoonotic Disease with respect to their educational level}

The attitude of respondents on zoonotic disease treatment, prevention, control, and advantage of vaccination with their educational level was assessed and the study revealed that statistically significant differences $(\mathrm{P}<0.05)$ were encountered. Of those who have a positive perception of zoonotic treatment, about $35.8 \%$ of respondents were having college and university level education while $49.2 \%$ of those who didn't have a positive perception of the zoonotic disease treatment were illiterate.

About $41.3 \%$ of those who have a positive perception of the possibility of zoonotic disease prevention were graduates of higher education whereas $39.5 \%$ of those who didn't have a positive perception of the possibility of zoonotic disease prevention were illiterate. Furthermore, the study depicted that the attitude of respondents towards zoonotic disease control possibilities was better in those with college and university educational level compared to those illiterates $(\mathrm{P}<0.05)$. However, no significant association $(\mathrm{P}>0.05)$ was seen among the different control methods of zoonotic disease and the educational level of the respondents. 


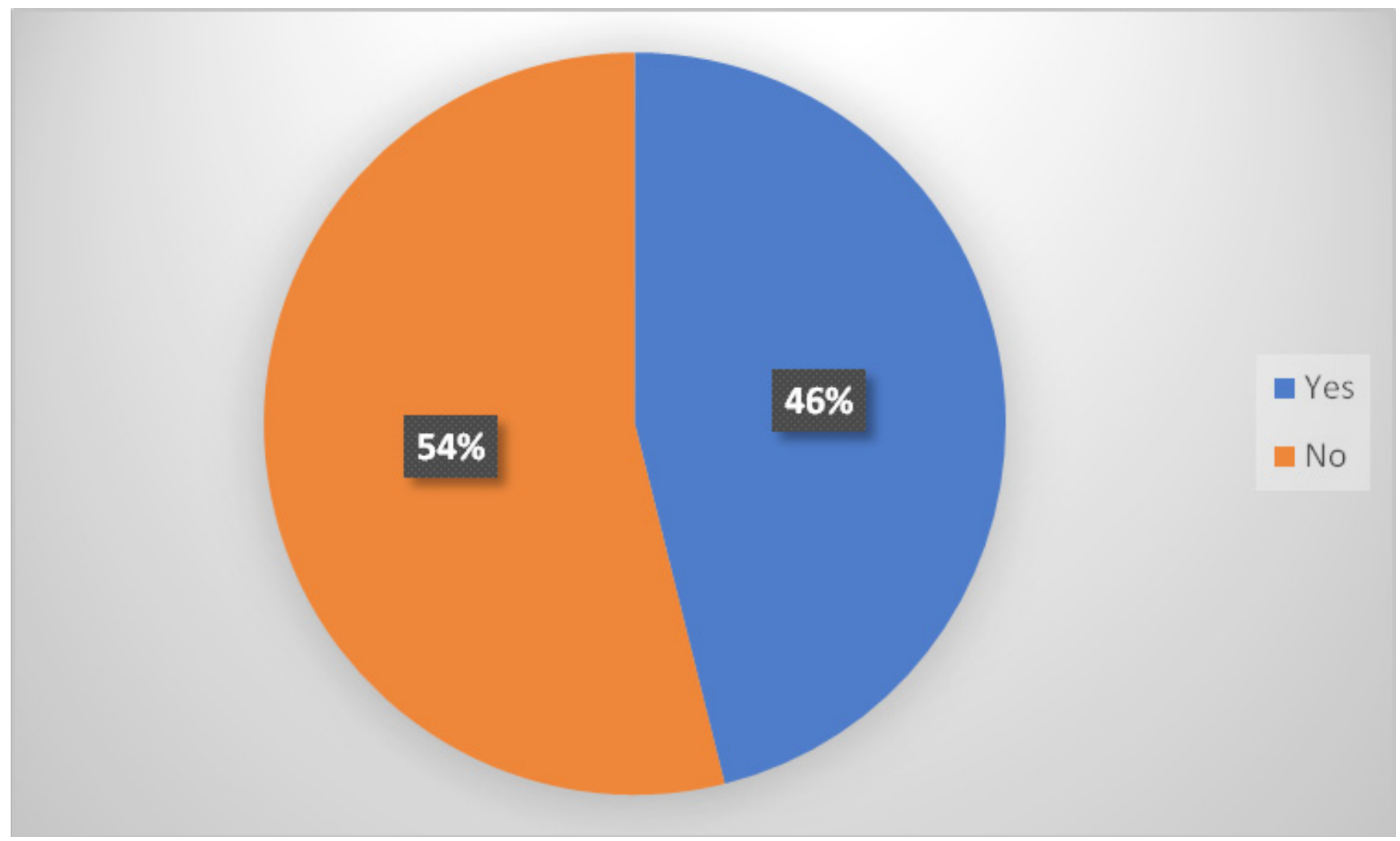

Figure 2: Response on the means of transmitting zoonotic diseases

Besides, $36.7 \%$ of the respondents who have a better perception on the advantage of vaccination to control diseases were college and university graduates whereas the majority of the respondents who didn't know the advantage of vaccination were illiterate and this association was statistically significant $(\mathrm{P}<0.05)$ (Table 3). 
Table 3. Comparison of educational level with the Attitude of respondents regarding zoonotic disease in Jinka

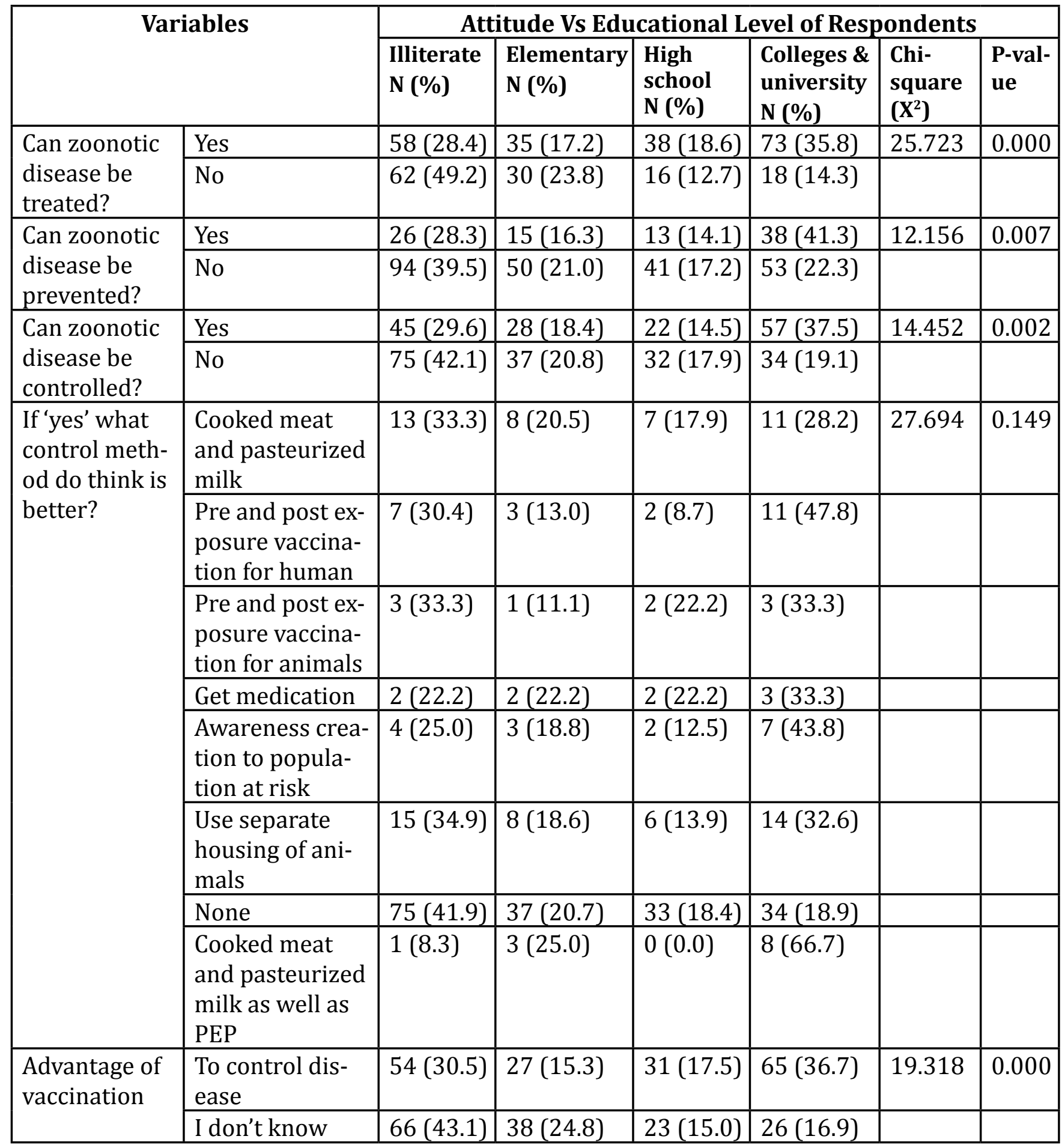

\subsection{Practice of the Respondents on Zoonotic Disease based on educational level}

The practice of the respondents towards zoonotic diseases along different educational levels was assessed and the result indicated that the majority of the respondents with lower educational levels had more contact as compared with those who had higher educational levels and this association found to be statistically significant $(\mathrm{P}<0.05)$. The practice of raw meat consumption was also found to be higher in those respondents with very low educational level compared to those with college and university education level $(\mathrm{P}<0.05)$. 
Similarly, there was a significant association between educational status and practice of respondents related to taking pre-exposure vaccination of respondents, handling of animal and immediate actions taken for infected animals with zoonotic diseases. Respondents with the educational levels of college and university had a good practice of preexposure vaccination and the majority of the respondents who didn't take immediate action after their animals were infected with zoonotic diseases were illiterate $(\mathrm{P}<0.05)$. Nevertheless, there was no statistically significant association exists between education and practice of the respondents towards vaccination of their animal and consumption of unpasteurized milk ( $\mathrm{p}>0.05)$ (Table 4$)$.

Table 4. Comparison of educational level with the practice of respondents regarding zoonotic diseases in Jinka






\section{DISCUSSION}

In this study; knowledge towards zoonotic disease related to age between 31-50 and male respondents has found $95.6 \%$ and $89.4 \%$, respectively. Thus, the community in the current study has found with lower knowledge towards zoonotic disease as compared to the previous report of Girmaet al., [25] from Addis Ababa that reports 100\% of respondents heard about the zoonotic disease. However, the current finding is higher than the previous finding of Gezmu et al., [15] who reports 76.8\% in Dodola town, West Arsi Zone, Ethiopia, Desta, [26] who reports 9 (5.8\%) in Afar and Andiappanet al., [27] who report 11\% in Malaysia. Besides, in the current investigation, a lower level (60.3\%) of knowledge, attitude, and practices about rabies was found by respondents of Debark Woreda, North Gondar. A relatively similar result was reported by Guaduet al. [28] about 64.1\% among the community of Bahir Dar town.

In the present study, the respondents who get their information about the zoonotic disease through training were $100 \%$. This finding was found higher from the report of Amenuet al. [29] from the Arsi-Negele district indicated that acquiring knowledge about zoonotic diseases from elders $(34.7 \%)$ and their observation $(32.7 \%)$ are the main source of information. This finding was also higher than the report of Gezmuet al., [15] who report (24.2\%) in Dodola Town. Besides, in this study, all respondents of health professionals (100\%) have a better knowledge of zoonotic diseases. This result was higher than the finding of Desta, [26] who reported (33.8\%) in Afar.

About $35.8 \%$ of college and university students had a better perception regarding the treatment of different zoonotic diseases whereas $41.3 \%$ of them had good perception regarding the prevention of different zoonotic diseases. The current report was much lower than that of Yalemebratet al., [10] in Debark Woreda, North Gondar that reported all respondents (100\%) have good perceptions regarding rabies. In contrast to the current report, Digafeet al., (30) 99.3\% of the people in Gondar Zuria, and Singh and Choudhary, [31] 98.6\% of the rural community in Gujarat, India, have previously heard about rabies. Jemberuet al., [32] also reported a high level of awareness (98\%) about rabies in Gondar Zone, Ethiopia.

The current investigation is also lower than the reports from Addis Ababa, Ethiopia, and India that reported 83 and $68.7 \%$, respectively [33][34]. The reason could be due to the difference in communication and information about animal diseases and differences in their level of education.

According to the present study, most respondents (46.1\%) have a relatively low level of knowledge on modes of transmission of zoonotic disease from animals to humans. This finding is comparable with the finding of Gezmuet al., [15] in Dodola Town that reported 50.5\%. In contrast, the current result was lower than the finding of Tesfayeet al., [35] from Jimma reported that dog bite (94.3\%) and raw/undercooked meat consumption (82.3\%) as a mode of transmission for rabies and taeniasis, respectively. The variation might be due to the difference in the educational status of respondents, where about $81.6 \%$ of respondents from Jimma were attending basic education. The findings on knowledge about zoonotic disease transmission from animal to human in the current study were higher than those reported by Kumaet al., [36] to be $15.6 \%$ from Mana and Limmukosa Districts of Jimma zone. The difference could be due to variation on educational status, where about $45.4 \%$ of the respondents from Mana and Limmukosa Districts didn't attend formal education. The current study was also higher than Amenuet al., [29] who reported $58.2 \%$ and $57.1 \%$ of study participants from Arsi-Negele district had a habit of consuming raw meat and unpasteurized milk, respectively.

In the present study, $38.3 \%$ of illiterate respondents consumed raw meat while $43.0 \%$ of illiterate respondents revealed the consumption of unpasteurized milk. In agreement with the current finding, Swaiet al., [22] from Arusha and Tanga of Tanzania reported that $40 \%$ of respondents consumed unpasteurized milk. In contrast to the present finding, the lower value was reported regarding zoonotic disease transmission from animal to human by Swaiet al., [22] indicated that about $16.3 \%$ of respondents consumed raw meat. This variation could be due to their habitat and cultural variation of the community from a different locality.

The current study revealed that about $40.4 \%$ of college and university respondents were sharing the same shelter with their animals in the study area. This finding was higher than that of Kumaet al., [36] reported who reported (18.8\%) that sharing the same shelter with animals in Mana and Limmukosa districts of Jimma Zone. This difference could be due to variation in the level of education of the respondents, and the difference in awareness towards zoonotic disease.

In the current study, $63.6 \%$ of college and university respondents have a preference for pre-exposure vaccination. In agreement with this study, almost all respondents agreed to consult health professionals in case of the animal bite was reported in Addis Ababa [33]. In contrast to this report, studies conducted in and around Gondar town, Ethiopia, reported about $62.2 \%$ of the study participants had strong beliefs in traditional medicine [30]. In Satkhira, Bangladesh, 
$59 \%$ of the dog bite victims first seek treatment from traditional healers instead of visiting the hospitals [37]. A higher (84\%) reliance on respondents on traditional treatment was reported from Dabat and Gondar [32]. The preference for vaccination might arise from the easy accessibility of modern medication, better educational level and the residence of the respondents.

The current study indicated a gap in community knowledge about the zoonotic disease and its mode of transmission. There was a low level of recognition about zoonotic diseases transmitted from animal to human and vice versa. The communities in the study area also indicated poor practices that could predispose to most zoonotic diseases. Regarding practices performed by the community, most respondents fail to vaccinate their animals, consumption of raw meat, and unpasteurized milk, sharing the same house with animals. Hence, continuous community motivation as well as provide better education and governmental officials` sensitization on mass awareness creation about zoonosis is crucial. Besides, health experts (veterinarians, veterinary public health, and physicians) are very important in the prevention and control of zoonotic diseases.

\section{CONCLUSION AND RECOMMENDATIONS}

This cross-sectional study has assessed the knowledge, attitude, and practices of Jinka residents towards zoonotic diseases and the role of education towards their attitude and practices with regard to zoonotic diseases. The study revealed that age, religion, education, occupation and marital status of the respondents were significantly associated with their knowledge on the zoonotic disease in which respondents with the age group greater than 15 years, orthodox and catholic religious affiliations, health professionals and married once had greater knowledge towards zoonotic disease. The role of education of the respondents on their attitude towards zoonotic disease treatment, prevention, control, and advantages of vaccine provision was found to be statistically significant. With regard to the practice of respondents towards zoonotic disease, education showed paramount importance on the ways of contact to animals, sharing of the same house with their animals, raw meat consumption, pre-exposure vaccination, ways of handling their health and infected animals in which respondents with lower educational level had higher contact with animals, consume more raw meat, didn't take pre-exposure vaccination and didn't take immediate action for infected animals by zoonotic diseases. In conclusion, awareness creation and training programs of Zoonotic disease transmission, treatment, prevention, and control should be provided to communities with lower educational status. Besides, the establishment of intersectoral engagement to control and prevention strategies for common zoonotic diseases should be enhanced. Accordingly, Imparting health education in one health approach towards the zoonotic disease of the Jinka community in general and to those at higher risk, in particular, is important.

\section{References}

1. Kloos H, Berhane Y. Zoonotic diseases of public health importance. Epidemiology and Ecology of Health and Diseases in Ethiopia 1st edition Edited by: Berhane Y, Hailemariam D, Kloos H Addis Ababa: Shama books. 2006:692-700.

2. Pelzer KD, Currin N. Zoonotic diseases of cattle. Virginia Coope Exten Prog pub. 2005:400-60.

3. World Health Organization. The control of neglected zoonotic diseases: a route to poverty alleviation Report of a Joint WHO/DFID-AHP Meeting with the participation of FAO and OIE. Geneva, Switzerland: WHO. 2005.

4. Mackenzie JS, Jeggo M, Daszak P, Richt JA. One Health: The Human-Animal-Environment Interfaces in Emerging Infectious Diseases: Food Safety and Security, and International and National Plans for Implementation of One Health Activities: Springer; 2016.

5. Anholt R-M, Stephen C, Copes R. Strategies for collaboration in the interdisciplinary field of emerging zoonotic diseases. Zoonoses and public health. 2012;59(4):229-40.

6. Greter H, Jean-Richard V, Crump L, Béchir M, Alfaroukh IO, Schelling E, et al. The benefits of'One Health'for pastoralists in Africa. Onderstepoort Journal of Veterinary Research. 2014;81(2):1-3.

7. Lindahl JF, Grace D. The consequences of human actions on risks for infectious diseases: a review. Infection ecology \& epidemiology. 2015;5(1):30048.

8. Taylor LH, Latham SM, Woolhouse ME. Risk factors for human disease emergence. Philosophical Transactions of the Royal Society of London Series B: Biological Sciences. 2001;356(1411):983-9.

9. Grace D, Mutua F, Ochungo P, Kruska R, Jones K, Brierley L, et al. Mapping of poverty and likely zoonoses hotspots. 2012.

10. Yalemebrat N, Bekele T, Melaku M. Assessment of public knowledge, attitude and practices towards rabies in Debark Woreda, North Gondar, Ethiopia. Journal of Veterinary Medicine and Animal Health. 2016;8(11):183-92.

11. Nkuchia M, Ruth L, Chris A, Henriette V. Infectious disease surveillance. Blackwell Publishing. 2007;538:980-1. 
12. Zewdie W, Wario E, Tehetna A. Assessment of Community Awareness on Common Zoonotic Disease in and around Yabello District of Oromia Regional State, Ethiopia. Multidisciplinary Advances in Veterinary Science. 2018;2(4):388-94.

13. Ameni G, Erkihun A. Bovine tuberculosis on small-scale dairy farms in Adama Town, central Ethiopia, and farmer awareness of the disease. Revue Scientifique et Technique-Office International des Epizooties. 2007;26(3):711-20.

14. Perseghin P, Bezzi G, Troupioti P, Gallina M. Streptococcus suis meningitis in an Italian blood donor. The Lancet. 1995;346(8985):1305-6.

15. Gezmu M, Bsrat A, Mekuria A. Assessment of Community Knowledge, Attitude and Practice on Zoonotic Disease in and Around Dodola Town, West Arsi Zone, Ethiopia. Ethiopian Journal of Veterinary Science and Animal Production. 2017;1:57-65.

16. Grant S, Olsen CW. Preventing zoonotic diseases in immunocompromised persons: the role of physicians and veterinarians. Emerging infectious diseases. 1999;5(1):159.

17. Lee K, Brumme ZL. Operationalizing the One Health approach: the global governance challenges. Health Policy and Planning. 2013;28(7):778-85.

18. Islam MA. Zoonoses in Bangladesh: the role of veterinarian in public health. Bangladesh Journal of Veterinary Medicine. 2014;12(2):93-8.

19. Papadopoulos A, Wilmer S. One Health: A Primer. National Collaborating Centre for Environmental Health. 2011.

20. Chomel BB. Control and prevention of emerging parasitic zoonoses. International journal for parasitology. 2008;38(11):1211-7.

21. Siembieda J, Huong NT, Hung P, Bandyopahyay S, Olowokure B. Prioritization of zoonotic diseases of public health significance in Vietnam. The Journal of Infection in Developing Countries. 2015;9(12):1315-22.

22. Swai ES, Schoonman L, Daborn C. Knowledge and attitude towards zoonoses among animal health workers and livestock keepers in Arusha and Tanga, Tanzania. Tanzania Journal of Health Research. 2010;12(4):272-7.

23. Mekonnen G, Enquselassie F, Tesfaye G, Semahegn A. Prevalence and factors affecting use of long acting and permanent contraceptive methods in Jinka town, Southern Ethiopia: a cross sectional study. Pan African Medical Journal. 2014;18(1).

24. Yamane T. Statistics: An introductory analysis. 2nd ed. New York: Harper and Row; 1967.

25. Girma S, Zewde G, Tafess K, Jibat K. Assessment of awareness on food borne zoonoses and its relation with veterinary public health services in and around Addis Ababa, Ethiopia. J Public Heal Epidemiol. 2012;4:48-51.

26. Desta AH. Knowledge, Attitude and Practice of Community Towards Zoonotic Importance of Toxoplasma Infection in Central Afar Region, North East Ethiopia. Int J Biomed Sci Eng. 2015;3:74-81.

27. Andiappan H, Nissapatorn V, Sawangjaroen N, Khaing S-L, Salibay CC, Cheung MMM, et al. Knowledge and practice on Toxoplasma infection in pregnant women from Malaysia, Philippines, and Thailand. Frontiers in microbiology. 2014;5:291.

28. Guadu T, Shite A, Chanie M, Bogale B, Fentahun T. Assessment of knowledge, attitude and practices about rabies and associated factors: in the case of Bahir Dar town. Global Veterinaria. 2014;13(3):348-54.

29. Amenu K, Thys E, Regassa A, Marcotty T. Brucellosis and Tuberculosis in Arsi-Negele District, Ethiopia: prevalence in ruminants and people's behavior towards zoonoses. 2010.

30. Digafe RT, Kifelew LG, Mechesso AF. Knowledge, attitudes and practices towards rabies: questionnaire survey in rural household heads of Gondar Zuria District, Ethiopia. BMC research notes. 2015;8(1):400.

31. Singh U, Choudhary S. Knowledge, attitude, behavior and practice study on dog-bites and its management in the context of prevention of rabies in a rural community of Gujarat. Indian Journal of Community Medicine. 2005;30(3):81.

32. Jemberu WT, Molla W, Almaw G, Alemu S. Incidence of rabies in humans and domestic animals and people's awareness in North Gondar Zone, Ethiopia. PLoS neglected tropical diseases. 2013;7(5).

33. Ali A, Ahmed EY, Sifer D. A study on knowledge, attitude and practice of rabies among residents in Addis Ababa, Ethiopia. Ethiopian Veterinary Journal. 2013;17(2):19-35.

34. Ichhpujani RL, Chhabra M, Mittal V, Bhattacharya D, Singh J, Lal S. Knowledge, attitude and practices about animal bites and rabies in general community--a multi-centric study. The Journal of communicable diseases. 2006;38(4):355-61.

35. Tesfaye D, Fekede D, Tigre W, Regassa A, Fekadu A. Perception of the public on the common zoonotic diseases in Jimma, Southwestern Ethiopia. International Journal of Medicine and Medical Sciences. 2013;5(6):279-85.

36. Kuma T, Deressa B, Alem F, Tigre W. Farmer's Awareness and Practices on Rabies, Bovine Tuberculosis, Taeniasis, Hydatidosis and Brucellosis in Mana and Limmukosa Districts of Jimma Zone, South West Ethiopia. World Applied Sciences Journal. 2013;23(6):782-7.

37. Ghosh S, Chowdhury S, Haider N, Bhowmik RK, Rana MS, Prue Marma AS, et al. Awareness of rabies and response to dog bites in a Bangladesh community. Veterinary medicine and science. 2016;2(3):161-9. 